https://doi.org/10.52676/1729-7885-2021-2-53-56

УДК 691.175 .2

\title{
STRUCTURE AND ELECTROPHYSICAL PROPERTIES OF PVDF+PbS/CdS NANOCOMPOSITES
}

\author{
A.A. Novruzova \\ Baku State University, Baku, Azerbaijan \\ E-mail:n.a_physicist@yahoo.com
}

In the given paper were investigated structure and electrophysical properties of $\mathrm{PVDF}+\mathrm{PbS} / \mathrm{CdS}$ nanocomposites. Distribution and the size of PbS and CdS nanoparticles in the polymer matrix has been studied by scanning electron microscopy (JEOL JSM-7600 F). The structure of the nanocomposite samples was investigated by the X-ray diffraction spectroscopy. The dependence of dielectric permittivity at frequency and temperature was investigated. It was shown that the dielectric permittivity of $\mathrm{PVDF}+\mathrm{PbS} / \mathrm{CdS}$ nanocomposite samples was increase in small nanoparticles content. Further increase in the concentration of the filler leads to decrease in the dielectric permittivity. The subsequent decrease in dielectric permittivity at higher nanoparticles content can be explained by the increase in defects in the structure of the nanocomposite.

Keywords: electrophysical dielectric permittivity properties, polyvinylidene fluoride, polymer nanocomposite, PbS, CdS.

\section{INTRODUCTION}

Nanocomposite materials are widely used in the areas of photonics, electronics, catalysis, energy storage, and biotechnology [1-7]. Polymer nanocomposites are receiving a fast-growing interest due to their large tunability of dielectric constant and easy processing. The dielectric properties are usually tuned by properly selecting the identity, shape, property of fillers, and engineering the interfaces between fillers and matrix [8]. Most of the current studies on dielectric polymer composites focus on the enhancement of the dielectric permittivity. From the point of view of increasing the composite's effective dielectric constant, the availability of inorganic fillers with dielectric constants on the order of hundreds and even thousands makes it very appealing to introduce them into polymers, which generally possess dielectric constants less than 10 . However, the resulting composites' effective dielectric constants generally fall short of expectations. Specifically, since the filler has a much greater permittivity than that of the polymer matrix, most of the increase in the effective dielectric constant comes through an increase in the average field in the polymer matrix, with very little of the energy being stored in the high permittivity phase [9]. The aim of this work is investigated structure and electrophysical properties of $\mathrm{PVDF}+\mathrm{PbS} / \mathrm{CdS}$ nanocomposites determine dielectric constant and dielectric loss, as a function of temperature and frequency.

\section{EXPERIMENTAL PART}

\subsection{Materials}

The polar polymer PVDF has the density of $1.78 \mathrm{~g} / \mathrm{cm}^{3}$ at $25^{\circ} \mathrm{C}$ and the melting point is $177^{\circ} \mathrm{C}$. Lead acetate $\mathrm{Pb}\left(\mathrm{CH}_{3} \mathrm{COO}\right)_{2}$, cadmium chloride $\left(\mathrm{CdCl}_{2} \times\right.$ 2,5 $\left.\mathrm{H}_{2} \mathrm{O}\right), \quad \mathrm{Na}_{2} \mathrm{~S} \times 9 \mathrm{H}_{2} \mathrm{O},(1-$ hexadecyl) trimethylammonium bromide $\left(\mathrm{C}_{19} \mathrm{H}_{42} \mathrm{BrN}, 98 \%\right)$, DMF have been purchased from Sigma Aldrich.

\subsection{Characterization}

Distribution and the size of $\mathrm{PbS}$ and $\mathrm{CdS}$ nanopar- ticles in the polymer matrix has been studied by scanning electron microscopy (SEM, JEOL JSM-7600 F).

$\mathrm{X}$-ray diffraction analysis was performed with Rigaku Mini Flex 600 XRD diffractometer at ambient temperature. In all the experiments, $\mathrm{Cu} \mathrm{K} \alpha$ radiation operating at $15 \mathrm{~mA}$ and $30 \mathrm{kV}$ was used. The samples were scanned in the $20-70^{\circ}$ range of Bragg angle $2 \theta$.

The frequency dependences of the dielectric permittivity and dielectric losses tangent were measured at a temperature $\mathrm{T}=298-433 \mathrm{~K}$ in the frequency range $\mathrm{f}=102-106 \mathrm{~Hz}$ using the dielectric spectroscopy (MNIPIE7-20).

\subsection{Synthesis of Nanocomposites}

Firstly $\mathrm{PbS}$ and $\mathrm{CdS}$ nanoparticles were synthesized by coprecipitation method in colloidal system [10]. Polymer composite materials were prepared as follow: PVDF was solved in DMF solution at room temperature, then nanoparticles of $\mathrm{PbS}$ and $\mathrm{CdS}$ were added to the polymer solution at a constant concentration of $3 \%$ and stirred for two hours to obtain a homogeneous mixture. The mixture was transferred to a Petri dish and dried, during $24 \mathrm{~h}$. Thin films of nanocomposite were obtained from these samples by hot pressing at the melting temperature of polypropylene and a pressure of $15 \mathrm{MPa}$. The films after hot pressing were cooled in water at a cooling rate of $200{ }^{\circ} \mathrm{C} / \mathrm{min}$.

\section{RESULTS AND DISCUSSION}

Figure 1 (a), (b) and (c) shows the SEM images of $\mathrm{PVDF}+\mathrm{PbS} / \mathrm{CdS}$ nanocomposites with $3 \mathrm{wt} \%$, $5 \mathrm{wt} \%$ and $10 \mathrm{wt} \%$ of $\mathrm{PbS} / \mathrm{CdS}$ nanoparticles respectively. As seen in the figures, the size of nanoparticles in the polymer matrix in the range of $48-83 \mathrm{~nm}, 73-88 \mathrm{~nm}$ and $79-90 \mathrm{~nm}$ in respectively. It is clear that with increasing content of nanoparticles in the polymer matrix, the size of nanoparticles also increases. Figure 2 reports the EDS analysis for the nanocomposites. From the EDS spectrum, it can be seen that the $\mathrm{PbS}$ and $\mathrm{CdS}$ are clearly shown. 


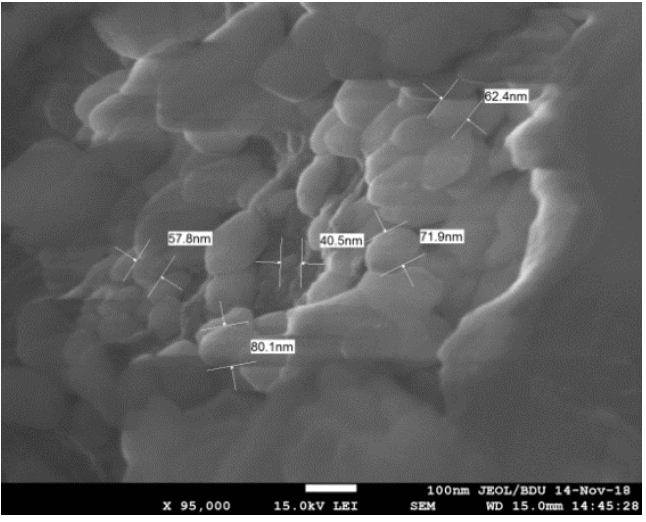

a)

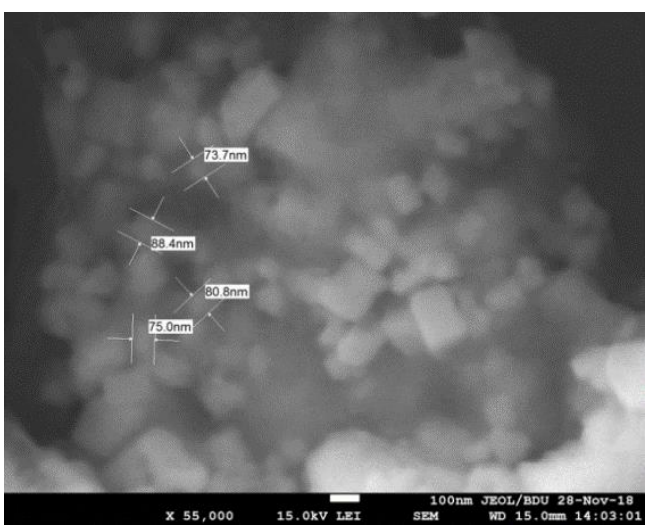

b)

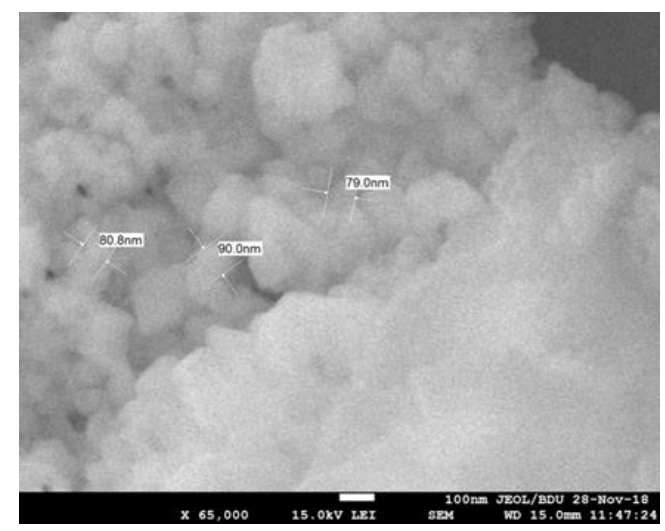

c)

Figure 1. SEM images of PVDF $+3 \% \mathrm{PbS} / \mathrm{CdS}(\mathrm{a})$, $P V D F+5 \% \mathrm{PbS} / \mathrm{CdS}(\mathrm{b})$, and PVDF $+10 \% \mathrm{PbS} / \mathrm{CdS}(\mathrm{c})$ nanocomposites

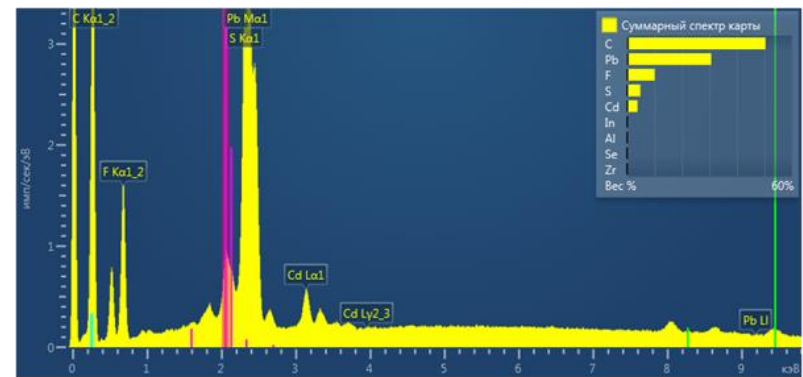

Figure 2. EDS spectra of $P V D F+P b S / C d S$ nanocomposite
Figure 3 shows X-ray diffractograms of pure PVDF and $\mathrm{PVDF}+\mathrm{PbS} / \mathrm{CdS}$ nanocomposite. As can be seen, the diffractogram of $\mathrm{PVDF}+\mathrm{PbS} / \mathrm{CdS}$ nanocomposite exhibits at $2 \theta$ the peaks $25.2(100)$, and 43.65 (220) characteristics of CdS and those ones $30.01(200)$ and $53.70^{\circ}$ (222) characteristics of PbS. Other peaks in the diffractogram belongs to the surfactant CTAB, which coats and stabilizes the surface of nanoparticles [10].

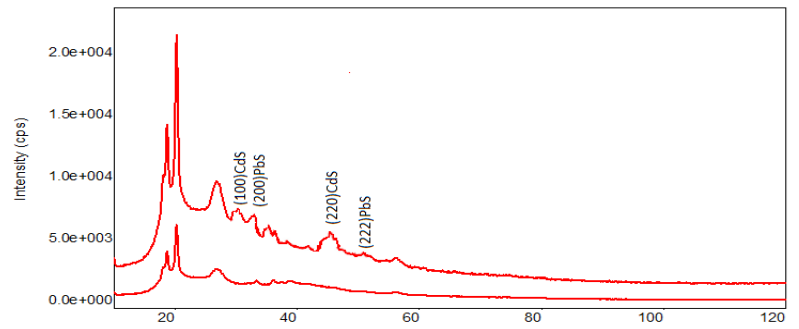

Figure 3. X-Ray diffraction patterns: 1 - pure PVDF, $2-P V D F+P b S / C d S$ nanocomposites

Figure 4 shows the frequency dependences of the dielectric permittivity (a) and dielectric loss tangent (b) of the pure PVDF and $\mathrm{PVDF}+\mathrm{PbS} / \mathrm{CdS}$ nanocomposites.

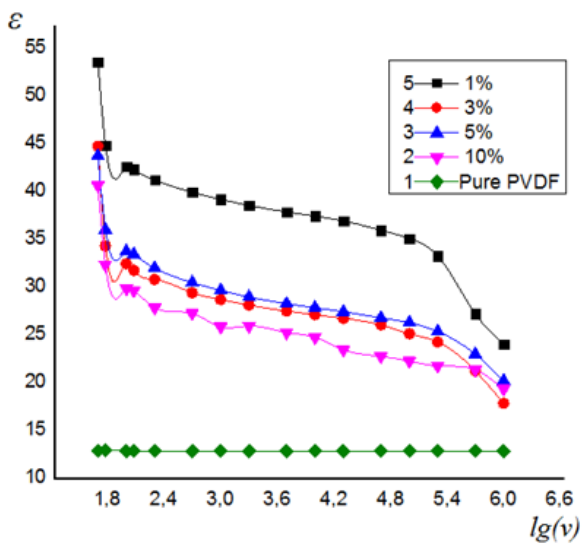

a)

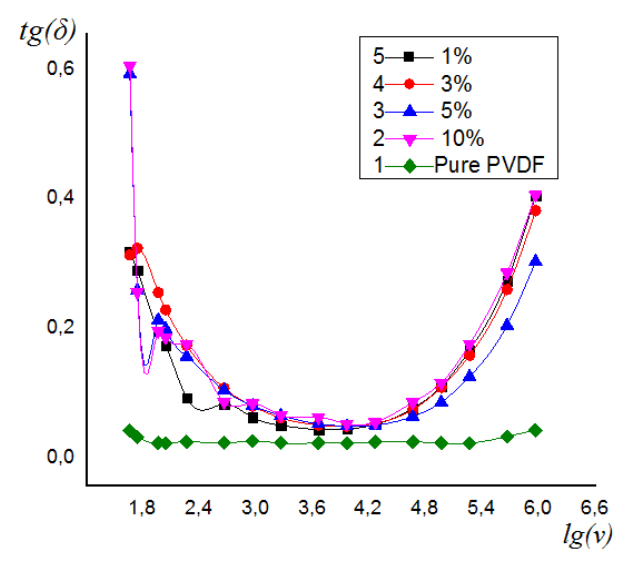

b)

Figure 4. a) Addiction of dielectric constant of pure $P V D F$ and composites $P V D F+P b S / C d S$ on frequency b) Frequency dependence of the dielectric loss tangent of pure $P V D F$ and $P V D F+P b S / C d S$ nanocomposites 
It can be seen in Figure 4 (a) that the incorporation of nanoparticles in the polymer matrix leads to the rise of the dielectric permittivity of the nanocomposite in low consentration content. The decrease in the dielectric permittivity at higher $\mathrm{PbS} / \mathrm{CdS}$ contents is associated with an increase in defects of the composite structure and decreasing of polarization. As can be seen from the Figure 4 (b), with the increasing frequency, the value of $\tan (\mathrm{d})$ of the $\mathrm{PVDF}+\mathrm{PbS} / \mathrm{CdS}$ nanocomposite increases. The sharp decrease in the dielectric loss with increasing of frequency can be explain due to high frequency energy losses.

Figure 5 shows the temperature dependence of the dielectric permittivity of the $\mathrm{PVDF}+\mathrm{PbS} / \mathrm{CdS}$ nanocomposites measured at a frequency of $1 \mathrm{kHz}$. It is shown that the value of the dielectric permittivity varies slightly with increasing temperature.

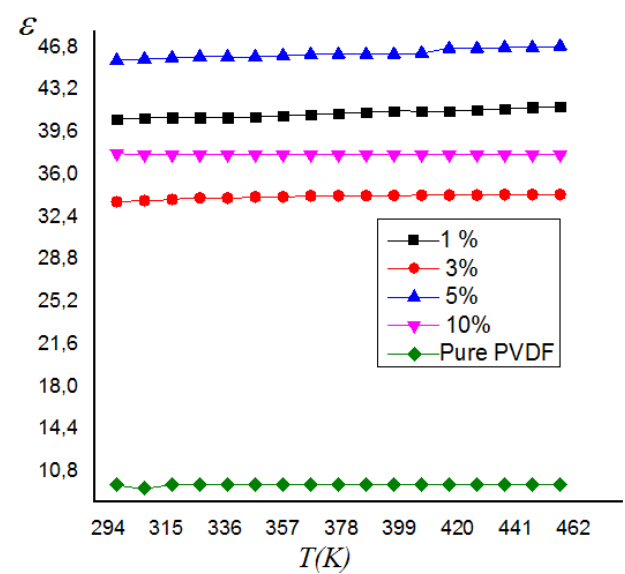

Figure 5. Dependence of dielectric permittivity of composites $P V D F+P b S / C d S$ on temperature

\section{CONClusion}

In the present work, structural and dielectric properties of $\mathrm{PVDF}+\mathrm{PbS} / \mathrm{CdS}$ nanocomposite has been investigated. The SEM analysis demonstrated the size of nanoparticles in the polymer matrix is $5-10 \mathrm{~nm}, 12$ $18 \mathrm{~nm}, 18-34 \mathrm{~nm}$ for $3 \%, 5 \%$, and $15 \%$ respectively. The structure of the nanocomposite has been investigated by XRD spectroscopy. The dielectric permittivity decrease with increasing consentration of nanoparticles. It is can be explain by the increasing defects in the structure of the nanocomposite. Dependence of dielectric permittivity of composites on temperature also was investigated. It is shown that the value of the dielectric permittivity varies slightly with increasing temperature.

\section{REFERENCES}

1. Mohsen Ahmadipour, Mohd Fadzil Ain, and Zainal Arifin Ahmad. "A short review on copper calcium titanate (CCTO) electroceramic: synthesis, dielectric properties, film deposition, and sensing application". In: Nano-Micro Letters 8.4 (2016), pp. 291-311.

2. Peter Barber, Shiva Balasubramanian, Yogesh Anguchamy, Shushan Gong, Arief Wibowo, Hongsheng Gao, Harry J Ploehn, and Hans-Conrad Zur Loye. "Polymer composite and nanocomposite dielectric materials for pulse power energy storage”. In: Materials 2.4 (2009), pp. 1697-1733.

3. Carole Jacques. Energy Storage Market Rises to $\$ 50$ Billion in 2020, amid Dramatic Changes. URL: http://www. luxresearchinc.com/news-and-events/press-releases/read/ energy-storage-market-rises-50-billion-2020-amiddramatic

4. Keun Hyung Lee, Joseph Kao, Saman Salemizadeh Parizi, Gabriel Caruntu, and Ting Xu. "Dielectric properties of barium titanate supramolecular nanocomposites". In: Nanoscale 6.7 (2014), pp. 3526-3531.

5. GM Ouyang, KY Wang, and XY Chen. "Enhanced electro-mechanical performance of $\mathrm{TiO} 2$ nano-particle modified polydimethylsiloxane (PDMS) as electroactive polymers". In: Solid-State Sensors, Actuators and Microsystems Conference (TRANSDUCERS), 2011 16th International. IEEE. 2011, pp. 614-617.

6. Tetsuji Inui, Hirotaka Koga, Masaya Nogi, Natsuki Komoda, and Katsuaki Suganuma. "High-dielectric paper composite consisting of cellulose nanofiber and silver nanowire". In: Nanotechnology (IEEE-NANO), 2014 IEEE 14th International Conference on. IEEE. 2014, pp. 470473.

7. Dong Kee Yi, Su Seong Lee, and Jackie Y Ying. "Synthesis and applications of magnetic nanocomposite catalysts". In: Chemistry of materials 18.10 (2006), pp. 2459-2461.

8. Inkai Yuan, Shenghong Yao, and Philippe Pouli. Dielectric Constant of PolymerCompositesand the Routes to High-k or Low-k Nanocomposite Materials. Polymer Nanocomposites.May 2016, (pp. 3-28).

9. Peter Barber, Shiva Balasubramanian, Yogesh Anguchamy, Shushan Gong, Arief Wibowo, Hongsheng Gao, Harry J. Ploehn and Hans-Conrad zur Loye. Polymer Composite and Nanocomposite Dielectric Materials for Pulse Power Energy Storage. Materials 2009, 2, 16971733; https://doi.org/10.3390/ma2041697

10. M. A. Ramazanov, A. M. Maharramov, A. Chianese, A. A. Novruzova, G. Y. Maharramova. The effect of electric discharge treatment on the optical properties of hybrid $\mathrm{pp} / \mathrm{pbs} / \mathrm{cds}$ nanocomposites. Journal of Ovonic Research Vol. 14, No. 2, March-April 2018, pp. 113-117.

11. Prateek, Thakur, Vijay Kumar, Gupta, Raju Kumar. Recent Progress on Ferroelectric Polymer-Based Nanocomposites for High Energy Density Capacitors: Synthesis, Dielectric Properties, and Future Aspects. Chem Rev 2016 Apr 13;116(7):4260-317. https://doi.org/ 10.1021/acs.chemrev.5b00495

12. Luo S, Yang W, Yu S, et al. Development and application of polymer-based nanocomposites dielectrics. In: 17th international conference on electronic packaging technology (ICEPT). 2016. https://doi.org/10.1109/ICEPT.2016. 7583165

13. Wang, Zijun, Zhou, Wenying, Sui, Xuezhen, Dong, Lina, Cai, Huiwu, Zuo, Jing, Chen, Qingguo. TemperatureDependent Dielectric Properties of Al/Epoxy Nanocomposites. Journal of Electronic Materials, 2016 Volume 45, Issue 6, pp. 3069-3078.

14. Sasidhar Siddabattuni, Thomas P. Schuman and Fatih Dogan. Dielectric Properties of Polymer-Particle Nanocomposites Influenced by Electronic Nature of Filler Surfaces. ACS Appl. Mater. Interfaces 2013,5 ACS Appl. Mater. Interfaces 2013, 5, 1917-1927. https://doi.org/ 10.1021/am3030239 


\title{
PVDF+PbS/CdS НАНОКОМПОЗИТТЕРІНІН ҚҰРЫЛЫМЫ МЕН ЭЛЕКТРОФИЗИКАЛЫК КАСИЕТТЕРІ
}

\begin{abstract}
А.А. Новрузова
Баку мемлекеттік университеті, Баку, Әзірбайжан

Бұл баяндамада $\mathrm{PVDF}+\mathrm{PbS} / \mathrm{CdS}$ нанокомпозиттерінің құрылымы мен электрофизикалық қасиеттерін зерттеу ұсынылған. Полимер матрицасындағы PBS және CdS нанобөлшектерінің таралуы мен мөлшерін зерттеу сканерлеуші электронды микроскопия (JEOL JSM-7600 F) арқылы жүргізілді. Нанокомпозит үлгілерінің құрылымын зерттеу рентген-дифракциялық спектроскопия әдісімен жүргізілді. Диэлектрлік өтімділіктің жиілік пен температураға тәуелділігі зерделенді. PVDF+PBS/CdS нанокомпозит үлгілерінің диэлектрлік өтімділігі нанобөлшектердің мөлшері аз болған кезде жоғарылағаны көрсетілген. Толтырғыш концентрациясын одан әрі арттыру диэлектрлік өтімділіктің төмендеуіне алып келеді. Нанобөлшектердің көп мөлшері кезінде диэлектрлік өтімділіктің одан әрі азаюын нанокомпозит құрылымындағы ақаулар санының артуымен түсіндіруге болады.

Tүйін сөздер: диэлектрлік өтімділіктің электрофизикалық қ̧асиеттері, поливинилиден фториді, полимерлік нанокомпозит, $\mathrm{PbS}, \mathrm{CdS}$.
\end{abstract}

\section{СТРУКТУРА И ЭЛЕКТРОФИЗИЧЕСКИЕ СВОЙСТВА НАНОКОМПОЗИТОВ PVDF+PbS/CdS}

\begin{abstract}
Новрузова А.А.
Бакинский государственный университет, Баку, Азербайджан

В данном докладе представлены исследования структуры и электрофизических свойств нанокомпозитов $\mathrm{PVDF}+\mathrm{PbS} / \mathrm{CdS}$. Исследование распределения и размера наночастиц $\mathrm{PbS}$ и $\mathrm{CdS}$ в полимерной матрице проводилось с помощью сканирующей электронной микроскопии (JEOL JSM-7600 F). Изучение структуры образцов нанокомпозита проводилось методом рентген-дифракционной спектроскопии. Изучалась зависимость диэлектрической проницаемости от частоты и температуры. Было показано, что диэлектрическая проницаемость образцов нанокомпозита PVDF+PbS/CdS увеличивалась при малом содержании наночастиц. Дальнейшее увеличение концентрации наполнителя приводит к уменьшению диэлектрической проницаемости. Дальнейшее уменьшение диэлектрической проницаемости при большем содержании наночастиц может объясняться увеличением количестве дефектов в структуре нанокомпозита.
\end{abstract}

Ключевые слова: электрофизические свойства диэлектрической пронииаемости, поливинилиден фторид, полимерный нанокомпозит, $\mathrm{PbS}, \mathrm{CdS}$. 